here and, year after year, sing the same old tune. It is just as full of discord this year as it was last year and the year before that. To the question "How much potash?" working upon identically the same sample, New Hampshire say's i2.I3 per cent., New Jersey 12.76, New York and Maine 12.94, and North Carolina I.3.08 per cent. and 1.3 .22 per cent. Now here is a difference of considerably more than one per cent. in tine same material, and that too, scattered along the whole gamut of rising estimates. Can these be considered "fairly accurate results?"

If we turn to our German friends, we find nore unaninity but by no means complete agreement. Their answers to the same questions range from 13 . I o per centt. to $13.4+$ per cent. Now who in this "confusion" of chemical tongues, has given us the right answer? Even on the face of it, is there not enough to suggest that there may be something wrong with the chenistry as well as the chemists?

Notwithstanding the riews and tabulated determinations above given, sour reporter has no changes in existing methods to suggest. He only desires that the investigations he has outlined shall be submitted to careful re-examination. especially the "occlusion" of potash salts in precipitates, and that the relation of this as yet obscure phenomenon, to potash deter. mination ( a source of the error to which, so far as he is aware, the writer has now for the first time directed attention), should be made the subject of thorongh investigation and review. If his conclusions are confirmed, changes are sure to come. Until then it seems the wiser course to adhere to existing nethods.

[CONTRIBUTIONS FROM THE ANALTTICAL LABORATORIFS OF THI SCHOOI. of Mines, Coltumia Cold.hgF,-No.4.]

\title{
GANTTER'S PROCESS FOR DETERMINING THE IODINE FIGURE OF FATS.
}

By PARKer C. MCILHINEY, Fi.B., A.M.

Receiver March 3i, 8844 .

F. Gantter, (Ztschr, anal. Chem., 32, i 78 and I8I) proposes a new method of deternining the iodine figure of fats and oils in which he uses carbon tetrachloride as a solvent for both the fat and iodine and uses no mercuric chloride as in the Hübl pro- 
cess. He states that the figures obtained when mercuric chloride is used depend upon the amount used. The results which he obtained and from which he draws these conclusions are as follows :

\begin{tabular}{|c|c|c|c|c|c|c|c|c|}
\hline & & bstanc & & $\begin{array}{c}\text { Amoun } \\
\text { use }\end{array}$ & odine & $\begin{array}{c}\text { A mout } \\
\text { us }\end{array}$ & $\mathrm{HgCl}_{2}$ & $\begin{array}{l}\text { Iodine } \\
\text { figure. }\end{array}$ \\
\hline 0.10 & at & liuse & ed-oil.... & 0.100 & ram. & 0.050 & ram. & 83.5 \\
\hline "، & " & “" & “... & 0.600 & "6 & 0.000 & $" 1$ & $85 \cdot 3$ \\
\hline " & " & " & $" \ldots$ & 0.150 & $"$ & 0.250 & "، & 141.0 \\
\hline " & “ & $"$ & $" \ldots$ & 0.150 & ‘ & 0.500 & " & 148.0 \\
\hline " & " & " & $" \ldots$ & 0.600 & " & 0.250 & " & 156.4 \\
\hline " & " & $"$ & $" \ldots$ & 0.600 & " & 0.500 & " & 173.6 \\
\hline$"$ & “ & “ & $" \ldots$ & 0.600 & “" & I.000 & " & I 88.4 \\
\hline " & " & lard & $\ldots \ldots \ldots \ldots$ & 0.500 & $"$ & 0.000 & " & 25.0 \\
\hline " & $"$ & $"$ & $\ldots \ldots \ldots \ldots$ & 0.500 & “" & 0.250 & "“ & 61.0 \\
\hline$"$ & $" “$ & " & $\ldots \ldots \cdots \cdots$ & 0.500 & $"$ & 0.500 & $"$ & 63.0 \\
\hline ". & " & “ & $\ldots \ldots \ldots \ldots$ & 0.500 & 16 & 1.000 & $"$ & 85.1 \\
\hline
\end{tabular}

$\mathrm{His}$ results prove that the amount of mercuric chloride present influences the results and that a very large excess of Hiibl's reagent would give a higher figure for linseedoil than a moderate excess, but they certainly do not justify the conclusion which he draws from them that the use of mercuric chloride is unnecessary, and it is on this assumption that the accuracy of his process depends.

To ascertain whether fats would absorb from a solution of iodine alone in any suitable solvent as much iodine as would be necessary to convert them into saturated bodies, portions of a sample of oleic acid were treated with measured quantities of solutions of iodine in alcohol, carbon disulphide, and carbon tetrachloride. All these solvents dissolve both the oleic acid and iodine.

The results were as follows:

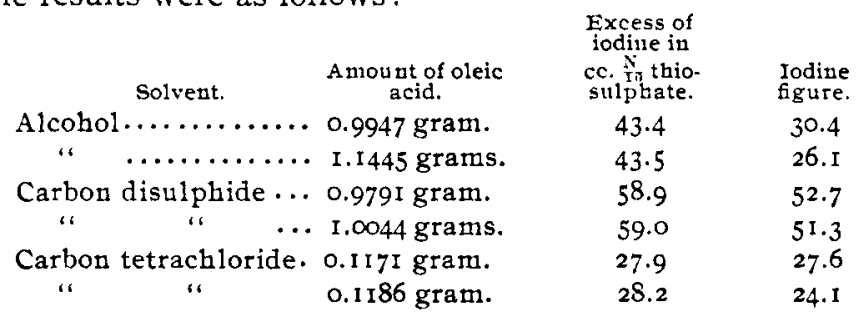

The iodine figure of the sample as determined by the $\mathrm{Hübl}$ process was 80.0 . 
These results show that iodine alone will not saturate fats and if it is used for this purpose its action must be assisted by mercuric chloride. Gantter's process, therefore, does not determine the iodine figure but an arbitrary figure which is not comparable with the results obtained by any other process.

\title{
THE CHEMICAL AND PHYSICAL EXAMINATION OF PORTLAND CEMENT.
}

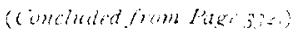

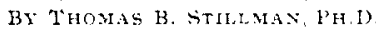 \\ REFERENCES (I 870 to I 892$)$.
}

188.4

Transactions of the Ancrican Suchity of Cizil Engineers.-Method for ascertaining bulk of given weights, 23 $_{3}$ 5.5. Cement first used in England, 13, I62. Hydraulicity: how conferred upon mortars by the ancients, I3, 162. Cement mixed with plaster Paris, 13,64. Setting: curious failure and subsequent setting upon exposure to the air, 13, 65. Prelininary report of committee on a uniform system for testing cement, $13,53,63$, 65. Testing machines, 13,62 .

Transactions of the Anericun Institute of Wining Engineers.-Cement analyses, 180 .

Zeitschrift für Analytische Chemie.-Tntersuchungen über den Nachweis von Verfälschungen inn Portland Cennent, 175 .

Jahresbericht (Wagner.)-Herstellung ron Cement (L. Roth), 69r; (W. Lesley), 69r. Das basische Futter fiir Cenentöfen von F. Morbitzer, 691. Cementbrennöfen von C. Dietszch, 69l. Behandlung der Cenente mit Wasser (H. Lechatelier), 695. I. Tetmajer üher: I. Reinen Etagonofen Cement. 2. An der Luft zerfallenes Mehl aus dem Etagenofen. 3. Reinen Schachtofen-Cement. 4. An der Luft zerfallenes Mehl aus einem Schachtofen. 5. Portland Cennent, genatnlen aus Schacht und Etagenofenklinkern, wie das in der Fabrik bein gleichzeitigem Betriebe vieler Ofensysteme üblich ist: 693. Ueber Gemische ans Kieselsäure und Ca1. ciumoxyd in Cemente (F. Landrin) 695. Restimmung der Thonerde im Cement (H. Prunier), 697. Versuchsresultate über j94 verschiedene Cement probeu (Böhne), 698. Prüfungsvorschriften für Cenent ausgestellt von der Gesellschaft der amerikanischern Civilingenieure, 699. Tetmajer Rammeapparat, 701 . Verfahren zur Prïfung von Portlanc Cement (IV. Michaelis), 704. Ceber specifisches Gewicht Cenenten (R. Fresenius), 707. Die Wirkung der Zumischmittel aurPortland Cement (Tetmajer, 7II. Magnesia im Cement (L. Erinenger), 7I2. T'm Cennent für stereochromatische Bemalung (V. Koch), $; 1.3$.

$$
1885 \text {. }
$$

Chemisches Central-Blatt.-Werth des Cementes (Iteris), 413. Cement für stereochromatische Bemalung 255. Oelfarbenanstrich darauf Cement, 975 . 